\title{
SV. CYRIL A METOD A ICH REFLEXIA V KRAJINE SLOVENSKA ${ }^{1}$
}

\section{Sts. Cyril and Methodius and Their Reflection in the Landscape of Slovakia}

\author{
Magdaléna Nemčíková - Alfred Krogmann - Daša Oremusová - \\ Vitor Ambrosio - Franciszek Mróz
}

DOI: $10.17846 / C L .2020 .13 .1 .224-236$

\begin{abstract}
NEMČÍKOVÁ, Magdaléna - KROGMANN, Alfred - OREMUSOVÁ, Daša AMBROSIO, Vitor - MRÓZ, Franciszek. Sts. Cyril and Methodius and Their Reflection in the Landscape of Slovakia. The formation of the Cyrillo-Methodian tradition in our history has an impact on the cultural landscape. The aim of the paper is a spatial identification of the cult of Sts. Cyril and Methodius as well as the study of its impact on the landscape of Slovakia. The first step is to identify tangible and intangible features, or, more precisely, cultural landscape elements. In Slovakia, we register in connection with Sts. Cyril and Methodius more than 120 sacral objects (churches, chapels, exterior sculptures). These, together with profane objects (schools, medical facilities) and intangible elements (e.g. street names, squares, organized events), are involved in the transformation of cultural, or, more precisely, religious landscape. The largest number of sacral objects arose after 1989, in the process of modern sacralisation of the landscape, which is typical of countries with renewed religious freedom.
\end{abstract}

Keywords: cultural landscape, Sts. Cyril and Methodius, sacralisation, sacral objects, religious landscape

\begin{abstract}
Abstrakt: NEMČÍKOVÁ, Magdaléna - KROGMANN, Alfred - OREMUSOVÁ, Daša AMBROSIO, Vitor - MRÓZ, Franciszek. Sv. Cyril a Metod a ich reflexia v krajine Slovenska. Formovanie cyrilo-metodskej tradície v našich dejinách má dopad aj na kultúrnu krajinu. Cielom príspevku je priestorová identifikácia kultu sv. Cyrila a Metoda ako aj skúmanie jeho vplyvu na krajinu Slovenska. Prvým krokom je identifikácia hmotných a nehmotných znakov, resp. prvkov kultúrnej krajiny. Na Slovensku evidujeme v súvislosti so sv. Cyrilom a Metodom viac ako 120 sakrálnych objektov (kostoly, kaplnky, exteriérové sochy). Tie sa spolu s profánnymi objektami (školy, zdravotnícke zariadenia) a nehmotnými prvkami (napr. názvy ulíc, námestí, organizované podujatia) podielajú na transformácii kultúrnej resp. religióznej krajiny. Najväčší počet sakrálnych objektov vznikol po roku 1989, teda v procese novodobej sakralizácie krajiny, ktorý je typický pre krajiny s obnovenou náboženskou slobodou.
\end{abstract}

Klúčové slová: kultúrna krajina, sv. Cyril a Metod, sakralizácia, sakrálne objekty, religiózna krajina

\footnotetext{
Táto práca bola podporená Agentúrou na podporu výskumu a vývoja na základe Zmluvy č. APVV-180185 Transformácia využívania kultúrnej krajiny Slovenska a predikcia jej d’alšieho vývoja, projektom VEGA č. 1/0934/17 Transformácia využívania kultúrnej krajiny Slovenska za ostatných 250 rokov a predikcia jej dalšieho vývoja a projektom Horizon 2020 č. 870644 - SPOT Social and innovative Platform On cultural Tourism and its potential towards deepening Europeanisation.
} 


\section{Úvod}

Cyrilo-metodská tradícia nie je len súčastou našich dejín, ale aj jej aktuálna prítomnost̉ má svoje opodstatnenie. Z dôvodu širokospektrálnosti jej dopadu na našu spoločnost̉ je predmetom výskumu viacerých vedných disciplín, geografiu nevynímajúc. Vzhladom na významnost̉ tejto tradície je cielom príspevku priestorová identifikácia kultu sv. Cyrila a Metoda, ako aj skúmanie jeho vplyvu na krajinu Slovenska.

\section{Transformácia kultúrnej krajiny}

V každom období si človek vytváral iný prístup k využívaniu krajiny, ktorej súčastou je aj kultúrna krajina. Tento pojem sa podla Iru a Uher $(2018,196)$ v geografickej literatúre objavuje v 90. rokoch 19. stor. Žigrai $(2000,229)$ ju definuje ako hybridný otvorený prírodno-antropogénny systém, ktorý je výsledkom pôsobenia človeka a ludskej spoločnosti v priestore a v čase. Súčasná kultúrna krajina predstavuje podla Boltižiara et. al. $(2014,12)$ určitý časový konglomerát, v ktorom sa prelínajú prvky alebo časti doznievajúcich časovo starších kultúrno-krajinných vrstiev s mladšími. Najčastejšie sa pri transformácii kultúrnej krajiny analyzuje jej časová a priestorová dimenzia, ako aj jej znaky, ktoré predstavujú jej charakteristické vlastnosti a špecifiká. Identifikáciu hmotných a nehmotných (duchovných) znakov kultúrnej krajiny považuje viacero autorov (Žigrai 2000, 232; Boltižiar et al. 2014, 15; Ira - Uher 2018, 197; Šantrůčková et al., 2019, 51 a i.) za základný predpoklad jej d’alšieho štúdia, resp. procesov v nej. V súvislosti s dosahom cyrilo-metodskej tradície na krajinu môžeme v súlade s Havlíčkom a Hupkovou (20007, 161; 2014, 103-104) konštatovat', že sa kultúrna krajina transformovala na religióznu krajinu v užšom slova zmysle. V prípade historických objektov a areálov súvisiacich so sv. Cyrilom a Metodom ide v zmysle Hubu ed. (1988) o fragmenty historických štruktúr, ktoré zohrávajú najmä v krajine s rovinatým reliéfom významnú krajinotvornú úlohu. Ak sú tieto objekty, resp. segmenty krajiny, zachované, hovoríme o nich ako o pozitívnej zložke súčasnej krajiny (Lacika 2015, 359).

Teoretické východiská skúmanej problematiky vychádzajú aj z prác, v ktorých bola cyrilo-metodská téma spracovaná predovšetkým z časovo-priestorového hladiska. Z prác, v ktorých sa kladie dôraz na hmotné, ako aj nehmotné kultúrne cyrilo-metodské dedičstvo je potrebné spomenút aspoň niekol'ko. Ivanič $(2018,77)$ sa vo svojej práci venuje okrem iného aj vybraným sakrálnym objektom z 19. a 20. Storočia, ako aj nehmotnému dedičstvu na príklade názvov ulíc či škôl súvisiacich s Cyrilom a Metodom v meste Nitra. Hetényi (2019) vo svojom príspevku analyzuje vplyv cyrilo-metodského kultu na religiozitu obyvatelsstva. K prácam regionálneho charakteru môžeme zaradit knihu Bagina z r. 1985, v ktorej detailne popisuje 41 sakrálnych objektov rímskokatolíckej cirkvi venovaných sv. Cyrilovi a Metodovi z celého Slovenska. Janas (2019, 109112) charakterizuje pamiatky s cyrilo-metodskou tematikou na regionálnej úrovni - v okrese Považská Bystrica. Cyrilo-metodské dedičstvo na lokálnej úrovni (v troch obciach na Spiši Torysky, Oľšavica a Nižné Repaše) analyzuje vo svojom príspevku Šturák (2004, 80-88).

\section{Vplyv sv. Cyrila a Metoda na krajinu}

Prvky kultúrnej krajiny s vplyvom kultu sv. Cyrila a Metoda môžeme aj vzhladom na ich kultúrno-historickú hodnotu rozdelit v zmysle Zákona č. 49/2002 Z. z. (Zákon o ochrane pamiatkového fondu 2020) podla povahy na hmotné a nehmotné. Ku hmotným prvkom zaradujeme nehnutelné (sakrálne objekty, profánne objekty a kombinované diela prírody a človeka) a hnutelné veci, resp. pamiatky (napr. interiérové plastiky, pamätné tabule, erby a pod.). 
Do kategórie nehmotných vecí patria napr. názvy ulíc, mestských častí, geografické a katastrálne názvy a pod. V súvislosti s témou článku sa detailnejšie venujeme najmä kategóriám nehnutelné a nehmotné veci. Z kategórie hnutelných vecí analyzujeme jedine erby, kedže práve tie sa môžu objavit priamo v krajine (napr. na vstupných tabuliach do obcí).

\section{Sakrálne objekty}

Na území Slovenska sa nachádza 106 väčších sakrálnych objektov (kostoly a kaplnky), ktorých patrocínium je v spojitosti s Cyrilom a Metodom (mapa 1). Až 74,5 \% z nich je rímskokatolíckych, 15,1 \% je pod správou gréckokatolíckej cirkvi, pravoslávna cirkev spravuje 7,6 \% objektov, evanjelická cirkev augsburského vyznania $0,9 \%$ a dva objekty (1,9\%) - Kostol sv. Cyrila a Metoda v Malom Krtíši a nemocničná Kaplnka sv. Cyrila a Metoda v Bratislave-Petržalke - majú ekumenický charakter. Z hladiska konfesionálnej variability, ako aj početnosti sa najviac sakrálnych objektov (25,5 \%) nachádza v Prešovskom samosprávnom kraji, za ním nasledujú kraje Košický (17 \%), Žilinský (16 \%) a Trenčiansky (15,1 \%). Najmenej sakrálnych objektov sme identifikovali v Bratislavskom samosprávnom kraji. V grafe 1 je znázornené rozdelenie sakrálnych objektov $\mathrm{v}$ jednotlivých krajoch podla cirkvi a typu objektu. V rámci nižších administratívnych jednotiek sme najvyššiu početnost̉ objektov zaznamenali v okresoch Žilina (4 kostoly a 4 kaplnky), Prešov (7 kostolov a 1 kaplnka) a Trebišov (5 kostolov). V 25 okresoch Slovenska sa nevyskytuje kostol alebo kaplnka zasvätená solúnskym bratom.

Z časového hladiska môžeme rozdelit obdobie vzniku sakrálnych objektov zasvätených Cyrilovi a Metodovi do piatich etáp (graf 2). Až do konca 18. stor. absentovali solúnski bratia medzi patrónmi kostolov, kaplniek a neexistovali ani informácie o oltároch s ich vyobrazením (Kowalská 2013, 70). V 19. stor. nastáva renesancia cyrilo-metodskej tradície aj vd’aka prípravám miléniových osláv príchodu sv. Cyrila a Metoda na Velkú Moravu (1863), úmrtia sv. Cyrila (1869), ako aj úmrtia Metoda (1885) (Ivanič 2018, 65). Najstaršie evidované patrocínium Cyrila a Metoda má rímskokatolícky kostol v obci Selce (okres Banská Bystrica). Gotický kostol zmenil 31. mája 1863 pôvodné patrocínium Všetkých svätých na Cyrila a Metoda (Judák - Poláčik 2009, 158) a stal sa tak podla Ivaniča $(2018,66)$ a Bagina $(1985,92)$ najstarším kostolom v celom Uhorsku s takýmto patrocíniom. Do prvej etapy (1863 - 1918) patria ešte dve sakrálne pamiatky v okrese Púchov rímskokatolícke kostoly v Dohňanoch (1865) a v Mojtíne (1875), ktorých patrocínium je pôvodné, pretože boli vystavané práve v tomto období (Bagin 1985, 50, 76). Do prvej etapy sme zaradili aj gréckokatolícky chrám v osade Podproč (okres Levoča), ktorý bol postavený v r. 1801, ale až od r. 1882 bol zasvätený sv. Cyrilovi a Metodovi (Novický 2010, 2). Kvôli excentrickej polohe, ako aj absencii stáleho obyvatelstva v osade, bol chrám viackrát vykradnutý a zničený. V r. 2007 - 2009 bol novozrekonštruovaný a následne znovu posvätený. Do grafu 2 sme nezaradili jediný evanjelický klasicistický Kostol sv. Cyrila a Metoda v Bardejove. Kostol bol síce posvätený už 25. septembra 1808, ale z dostupných prameňov nebolo možné identifikovat', v akom období získal pomenovanie po solúnskych bratoch (ECAV Bardejov 2020; Antony 2008, 5; Klátik 2018, 322-323). V medzivojnovej etape (1918 - 1938) vzniklo 19 objektov (10 kostolov a 9 kaplniek). Medzi inými aj kostoly vo Velkých Držkovciach (okres Bánovce nad Bebravou) a v mestskej časti Košice-Krásna. Obidva kostoly majú nielen vysokú architektonickú hodnotu (Bagin 1985, 127), ale sú v krajine dominantným prvkom, ktorý sa podiel’a na vytváraní jej „genia loci“ (Heinrichová 2012, 43). Počas tretej etapy (1939 - 1945) bolo vysvätených 8 rímskokatolíckych objektov (5 kostolov a 3 kaplnky). Kostol v Giraltovciach (1940) tvorí nielen svojím zaujímavým secesným vzhladom, ale aj polohou na vyvýšenom mieste, dominantu krajiny. Po druhej svetovej vojne, počas štvrtej etapy (1946 - 1988) bol v Terchovej v r. 1949 postavený najväčší kostol s patrocíniom sv. Cyrila a Metoda 
na Slovensku. Kostol v Lehote pod Vtáčnikom predstavuje podla Bagina $(1985,129)$ architektonický vrchol medzi cyrilo-metodskými sakrálnymi objektmi. Kostol vo funkcionalistickom slohu je od roku 1963 národnou kultúrnou pamiatkou (Pamiatkový úrad SR 2019). V zmysle Laciku (2015, 363-365) sme tento objekt identifikovali ako solitérny prvok súčasnej kultúrnej krajiny, ktorý má západnú okrajovú polohu v rámci sídla. Počas štvrtej etapy, ktorá bola aj druhá najdlhšia (43 rokov) vzniklo na území Slovenska 24 sakrálnych objektov zasvätených sv. Cyrilovi a Metodovi, pričom z 20 kostolov boli 2 gréckokatolícke a 2 pravoslávne. Situácia okolo gréckokatolíckeho kostola v Stropkove je príkladom politického vplyvu na vývoj formovania kvalitatívnych vlastností v krajine. Chrám bol postavený v r. 1949, ale vzhladom na politickú situáciu, bol následne v rokoch 1950 - 1968 zverený pravoslávnej cirkvi. Chrám postavený v zmysle gréckej sakrálnej architektúry bol síce dominantným prvkom v krajine, ale politické udalosti mali vplyv na zmenu spoločenských hodnôt krajiny ako genia loci, identity krajiny a aj krajinného rázu (Heinrichová 2012, 42). Po r. 1989, aj vdaka zvýšenému záujmu spoločnosti o náboženskú, ako aj národnú tému, nastáva zvýšený záujem o cyrilo-metodskú problematiku. Dokazuje to aj počet sakrálnych objektov v piatej etape (graf 2), z ktorých až 74 \% tvoria kostoly. Ide väčšinou o novostavby, napr. rímskokatolícky kostol v Rakoviciach (okres Pieštany) z r. 2005, gréckokatolícky kostol v obci Sol’ (okres Vranov nad Toplou) z r. 2008 či pravoslávny kostol v Holíči (okres Skalica), ktorý bol posvätený nedávno v r. 2018. V súlade s Matákovou $(2012,196)$ môžeme hovorit’ o novodobej sakralizácii krajiny. Boli postavené aj kostoly, ktoré stoja na mieste pôvodných kostolov, ktoré boli v zlom technickom stave. Pôvodný kostol v Železnej Breznici (okres Zvolen) z r. 1969 museli zbúrat', nový kostol bol vysvätený v r. 2010. Obdobne to bolo aj s najmenším kostolom zasväteným sv. Cyrilovi a Metodovi v obci Seniakovce (okres Prešov). V obci bol až do roku 1956 stredoveký kostol z 13. stor. zasvätený Svätému krížu, veriaci ho zbúrali a až v r. 1989 postavili na tom istom mieste nový Kostol sv. Cyrila a Metoda (Apsida, 2020). V tomto prípade môžeme konštatovat', že proces zmeny (odstránenie pamiatky s pridanou kultúrno-historickou hodnotou) mal na spoločenské hodnoty krajiny (genius loci, identita krajiny, ako aj celkový krajinný ráz) skôr negatívny dopad (Heinrichová 2012, 115). V r. 2002 bol v Malom Krtíši (okres Velký Krtíš) vybudovaný Kostol sv. Cyrila a Metoda, ktorý má charakter ekumenického chrámu, v ktorom sa striedajú veriaci evanjelickej cirkvi a. v. s veriacimi z rímskokatolíckej cirkvi (Farnost’ Vel'ký Krtíš, 2020). Paralelu môžeme pozorovat aj v prípade gréckokatolíckej Kaplnky sv. Cyrila a Metoda vo Svite, ktorá je súčastou rímskokatolíckeho Kostola sv. Jozefa - robotníka. Tento komplex bol vybudovaný v r. 1992. V oboch prípadoch sa očakáva postupná zmena spoločenských prejavov krajiny, spôsobená utváraním vztahov medzi veriacimi dvoch konfesií.

V blízkej dobe pribudnú k sakrálnym stavbám minimálne ešte dva kostoly. Od r. 2014 prebieha výstavba gréckokatolíckeho Chrámu sv. Cyrila a Metoda v Trenčíne a v r. 2022 by mal pribudnút v Nitre pravoslávny chrám, ktorý bude zasvätený Sedmopočetníkom, medzi ktorých sa radia aj sv. Cyril a Metod.

Historický, ale i estetický ráz kultúrnej krajiny dotvárajú aj sochy, ktoré zaradujeme k drobnej sakrálnej architektúre. Podobne ako v nehnutelných pamiatkach, aj sochy zobrazujúce Cyrila a Metoda vznikali najmä po r. 1989. K najstarším sochám patrí socha sv. Cyrila a sv. Metoda v obci Rakovice (okres Pieštany) pochádzajúca z r. 1924. Zaujímavostou tejto pamiatky je nielen jej presun z pôvodného miesta, ale aj fakt, že až 3.7.2005 bol v tejto obci dostavaný a vysvätený Kostol sv. Cyrila a Metoda. Socha je aktuálne súčastou verejného priestranstva pred kostolom (Rakovice 2019). Z rovnakého obdobia pochádza aj súsošie Cyrila a Metoda v obci Trakovice (okres Hlohovec), ktoré vzhladom na svoju polohu môžeme označit ako „prícestná socha“ (Trakovice 2020). Z novodobých sôch patria k najznámejším súsošia solúnskych bratov v mestách Nitra, Žilina a Trnava. Na ich popularite sa okrem umeleckej hodnoty podiela práve ich výhodná 
lokalizácia v historických centrách miest. Svojou kultúrnou, ako aj estetickou hodnotou sa na vytváraní identity regiónu podielajú aj sochy nachádzajúce sa v extraviláne obcí. Sochy sv. Cyrila a Metoda lokalizované vo vinohradoch obcí Vinodol či Branč sú toho dôkazom (Vinodol 2020, Branč 2020).

V prípade samostatných sôch sv. Cyrila a Metoda na známom novodobom mariánskom pútnickom mieste Hora Živčáková (okres Čadca) môžeme konštatovat', že ide zrejme o sochy, ktoré sa nachádzajú v rámci Slovenska nielen najsevernejšie, ale aj v najvyššej nadmorskej výške (cca 760 $\mathrm{m}$ n. m.). Samostatne stojace sochy zhotovené z umelého pieskovca boli vybudované v roku 2013, ked' sa na viacerých miestach konali oslavy 1150 . výročia príchodu vierozvestcov. Práve v období príprav na toto výročie, od roku 2010, vzniklo niekolko sochárskych diel s cyrilo-metodskou tematikou, ktoré boli inštalované napr. v mestách Nové Zámky (2011), Trnava (2012), Medzilaborce (2013), ako aj v obciach Velušovce (2011), Východná (2012), Hlinné (2012), Maňa (2013) a Diviaky nad Nitricou (2013). Okrem tradičného stvárnenia súsošia Cyrila a Metoda v sochárskom umení, existuje aj na území Slovenska zopár výnimiek. Okrem už spomínaných solitérnych sôch sv. Cyrila a Metoda na Hore Živčáková, k menej tradičným dielam môžeme zaradit aj bronzovú sochu svätého Konštantína Filozofa v Nitre z roku 2013. Zobrazenie len jedného z vierozvestcov korešponduje s faktom, že socha stojí pred hlavnou budovou Univerzity Konštantína Filozofa v Nitre. V prípade drobnej sakrálnej architektúry postavenej po r. 1989 môžeme v súlade s Matákovou (2012, 196) konštatovat', že v rámci novodobej sakralizácie krajiny sa ku náboženskému motívu pridali aj motívy historické, sociálne či kultúrne.

\section{Profánne objekty}

Okrem sakrálnych objektov, najčastejšie nesú pomenovanie späté s Cyrilom a Metodom budovy, kde sídlia najmä vzdelávacie inštitúcie. $Z$ vysokých škôl je to Univerzita sv. Cyrila a Metoda v Trnave, Univerzita Konštantína Filozofa v Nitre a Rímskokatolícka cyrilometodská bohoslovecká fakulta Univerzity Komenského. Stredné školy, ktoré majú v názve cyrilo-metodskú problematiku, sa nachádzajú v Nitre, Košiciach, Michalovciach, Humennom a Snine. Základné školy sa nachádzajú v Seredi, Spišskej Novej Vsi, Košiciach, Humennom, Snine, Žiline a v Starej Lubovni, kde je základná škola prepojená aj s materskou školou. V prípade stredných a základných škôl ide o cirkevné školy, ktorých zriad’ovatelmi sú rímskokatolícka, gréckokatolícka, ako aj pravoslávna cirkev. Zo zdravotníckych inštitúcií môžeme do tejto kategórie zaradit Nemocnicu sv. Cyrila a Metoda, ktorá je súčastou najväčšieho zdravotníckeho zariadenia na Slovensku - Univerzitnej nemocnice Bratislava.

\section{Kombinované diela človeka a prírody}

$\mathrm{V}$ rámci kombinovaných diel človeka a prírody sme identifikovali na Slovensku len tri parky, ktorých názov korešponduje s cyrilo-metodskou tematikou. Ide o parky v Martine, Kapušanoch a v Slovenskom Novom Meste. V Martine park obklopuje budovu Matice Slovenskej a v prípade Kapušian a Slovenského Nového Mesta ide o menšie areály, ktorým dominuje súsošie Cyrila a Metoda.

\section{Hnutel'né veci}

Cyrilo-metodskú symboliku sme identifikovali napr. v erbe obce Brodské (okres Skalica). V erbe tejto marginálnej obce dominujú dve postavy, ktoré sa interpretujú raz ako dvaja františkáni, 
inokedy ako sv. Cyril a Metod (Heraldický register SR 2019a). Druhým príkladom je erb obce Nová Bošáca (okres Nové Mesto nad Váhom). Ide tiež o prihraničnú obec, v ktorej erbe sú okrem typického stromu - slivky aj písmená $\mathrm{C}$ a $\mathrm{M}$, ktoré symbolizujú nové patrocínium Kostola sv. Cyrila a Metoda (Heraldický register SR, 2019b).

\section{Nehmotné veci}

V rámci štandardizovaných geografických názvov vydávaných Úradom geodézie, kartografie a katastra Slovenskej republiky sme neidentifikovali výskyt pomenovaní súvisiacich s Cyrilom a Metodom v názvoch vrchov, dolín, priesmykov a sediel, ako aj v názvoch vôd, chránených území či katastrálnych území (Úrad geodézie, kartografie a katastra, 2020). Absencia cyrilo-metodskej tematiky v geografických názvoch súvisí s vývojom tejto tradície na našom území. V období znovuzrodenia cyrilo-metodskej témy boli už v spoločnosti dávno vžité iné geografické názvy.

Podla Buchera $(2015,453)$ zohrávajú aj názvy centrálnych priestorov sídel (námestia, ulice) klúčovú úlohu pri utváraní ich identity. V ôsmich slovenských mestách (Bratislava-Devín, Košice-Krásna, Nitra, Poprad, Zvolen, Hlohovec, Sečovce a Vrbové) a v obci Slovenské Nové Mesto sa nachádzajú námestia pomenované po Cyrilovi a Metodovi. Ide skôr o menšie námestia, ktoré nie sú centrálnymi priestormi týchto sídel. Výnimku tvoria námestia v mestskej časti Košice-Krásna a v obci Slovenské Nové Mesto, ktoré sa nachádzajú v ich centrálnych zónach. Najčastejšie sú lokalizované na námestiach sochy Cyrila a Metoda (napr. Slovenské Nové Mesto), alebo kostoly s ich patrocíniom (Košice-Krásna, Poprad). Zaujímavostou sú napr. námestia v Nitre a Hlohovci, kde okrem názvu priestranstva nenájdeme nič, čo by sme mohli stotožnit’ s cyrilo-metodskou tematikou. V rámci názvov ulíc sme identifikovali na území Slovenska urbanonymá ako: sv. Cyrila a Metoda (výskyt 11 x - napr. Žilina, L’ubochňa, Terchová, Nový Ruskov (okres Trebišov), Brezovica (okres Tvrdošín) a i.), sv. Cyrila a sv. Metoda (Topolčany), Cyrila a Metoda (Bánovce nad Bebravou), Cyrilometódská (Nové Zámky, Branč (okres Nitra), Cyrilova (Bratislava, Nitra), Konštantínova (Stropkov), Metodova (Šaštín-Stráže, Nitra, Stropkov, Prešov, Bratislava), Nábrežie sv. Cyrila (Prievidza), Nábrežie sv. Metoda (Prievidza). Ulice sa nachádzajú bud' v blízkosti objektov pomenovaných po Cyrilovi a Metodovi, resp. len po jednom z nich (napr. kostoly (Terchová, L’ubochňa), školy (Michalovce)), alebo ich lokalizácia je v danom sídle náhodná, bez d’alších väzieb na cyrilo-metodskú tematiku. Dôležitú úlohu majú Cyril a Metod aj v rámci schematizmu jednotlivých cirkví. Napr. v rámci rímskokatolíckej cirkvi sú sv. Cyril a Metod patrónmi Žilinskej diecézy (2020), ako aj farností: napr. v Pieštanoch, Giraltovciach, Košiciach-Krásnej, Kriváni a i. Cyril a Metod sa objavujú aj v názvoch gréckokatolíckych farností, napr.: v Stropkove, Trenčíne, Lipanoch a i.

V súčasnosti môžeme pozorovat rozvoj cyrilo-metodských tradícií v niektorých obciach Slovenska i vo forme organizovaných podujatí. Najznámejšie pravidelné náboženské podujatia sa realizujú na týchto siedmich cyrilo-metodských pútnických miestach: Nitra, Ducové-Kostelec, Nadlice-Mechovička, Selce, Terchová, Sečovce a Stropkov. Detailnejšie sú pútnické miesta, ako aj cyrilo-metodské púte spracované v príspevku Krogmann et al. (2017, 184 - 186). Aktuálne sa tieto jednoúčelové akcie náboženskej (napr. výročné bohoslužby na sviatok sv. Cyrila a Metoda), resp. kultúrnej povahy (napr. spomienková slávnost pri príležitosti rôznych výročí týkajúcich sa solúnskych bratov) transformujú na komplexnejšie poňaté podujatia (slávnosti, festivaly atd’.). Stávajú sa tak významným faktorom regionálneho rozvoja jednotlivých lokalít, resp. regiónov. Mnoho destinácií na celom svete si vybudovalo portfólio organizovaných podujatí nielen ako strategickú iniciatívu na prilákanie návštevníkov, ale aj ako nástroj na rozvoj svojej vlastnej značky (Piva et al. 2017, 100). Historický význam vierozvestcov transformovalo do takejto ponuky sedem 
slovenských obcí. Podla portálu Slovakia.travel (oficiálny, centrálny propagačno-informačný systém cestovného ruchu SR), ktorý má propagovat Slovensko ako destináciu cestovného ruchu začali ako prví slávit vierozvestcov v obci Terchová (Slovakia travel 2020). V r. 2020 sa uskutoční už 31. ročník „Cyrilometodských dní. Návštevníkom je každoročne ponúkaný bohatý duchovný a kultúrny program. Podujatie, ktoré organizuje obec a miestna farnost', sa koná počas prvých júlových dní a vrcholí 5. júla, na sviatok sv. Cyrila a Metoda.

Bohatú tradíciu má aj podujatie „Nitra, milá Nitra...“, súčastou ktorého sú Pribinove a Cyrilo-metodské slávnosti v meste Nitra. Počas mestských slávností sa na sviatok sv. Cyrila a Metoda (5. júl) koná tradičná Cyrilo-metodská národná pút. Podujatie sprevádza množstvo kultúrnych, vedeckých podujatí, jarmok a iné atrakcie. Na popularite získal aj sprievodný náučný a zážitkový program „Po stopách sv. Cyrila a Metoda z Dražoviec cez Zobor do Nitry“, na ktorom participovali subjekty spolupracujúce na budovaní Európskej kultúrnej cesty sv. Cyrila a Metoda na území Nitrianskeho samosprávneho kraja. Na rovnakom historickom fundamente sa organizujú na Devíne (jedno z doložených centier Velkej Moravy spolu s Bratislavou a Nitrou) celoštátne oslavy Cyrila a Metoda.

Júlový sviatok sv. Cyrila a Metoda si uctievajú aj v Bardejove - Cyrilo-metodskými slávnostami ekumenickej jednoty. V r. 2020 sa bude konat už 25. ročník tohto podujatia. V rovnaký deň si odkaz solúnskych bratov pripomínajú aj návštevníci skanzenu v Starej Lubovni - na podujatí „Cyrilometodské slávnosti pod hradom Lubovňa“. Zaujímavostou býva slávenie svätej liturgie v staroslovienskom jazyku. Jedným z najpopulárnejších podujatí v obci Dohňany v okrese Púchov sú trojdňové „Cyrilometodské hodové slávnosti“ $s$ bohatým duchovným a kultúrnym programom venovaným predovšetkým miestnemu obyvatel'stvu.

Cyrilo-metodskú tematiku prezentuje od r. 2013 v rámci organizovaných podujatí aj obec Bojná, ktorá v lokalite národnej kultúrnej pamiatky hradiska Valy realizuje Cyrilo-metodské slávnosti. Okrem náboženského charakteru, majú slávnosti aj kultúrno-historicko-edukačný charakter, kedže súčastou jednodňového programu bývajú zvyčajne ukážky remesiel, kuchyne, zbraní, atrakcií z obdobia Vel'kej Moravy (Bojná, 2019). V programe figurujú odborné prednášky, ako aj aktivity pre najmenších. O zvyšovaní atraktivity tohto podujatia svedčí aj fakt, že do obce bola v r. 2019 v čase konania akcie zabezpečovaná doprava z Nitry, čím sa uvedená akcia stáva významným prvkom turistickej ponuky v Nitrianskom samosprávnom kraji (Lexikon 2019).

Knajmladším podujatiam, ktoré si pripomína slovanských vierozvestcov, patria Cyrilometodské dni v obci Horný Hričov. Prvý ročník sa uskutočnil 6. 7. 2019. Z obsahového hladiska však ide o podujatie gastronomického (varenie Pltníckeho guláša), športového (Cyrilometodský cross beh) a hudobného charakteru (Horný Hričov 2020).

\section{Záver}

Cyrilo-metodská tradícia prešla u nás viacerými transformáciami, čo bolo podla Hetényiho a Ivaniča $(2017,88)$ dôsledkom jej využívania a prispôsobovania sa ku konkrétnej dobe. V príspevku sme skúmali hmotné a nehmotné znaky, resp. prvky kultúrnej krajiny, ktoré majú súvis so sv. Cyrilom a Metodom. Signifikantný podiel nielen z hladiska počtu, ale aj vplyvu na krajinu mali väčšie sakrálne objekty (kostoly a kaplnky). Identifikovali sme 106 objektov pomenovaných po sv. Cyrilovi a Metodovi v 96 obciach, pričom sa až $73 \%$ sakrálnych objektov vyskytuje na vidieku. Práve na vidieku zohrávajú významnú krajinotvornú úlohu (napr. kostol v Selciach, Lehote pod Vtáčnikom a i.). Pokial' sa skombinuje výhodná poloha objektu (napr. vyvýšené miesto, excentrická poloha v rámci obce a i.) s jeho architektonickou hodnotou, stáva sa objekt dominantným prvkom religióznej krajiny a podiel’a sa aj na vytváraní jej genia loci, ako aj územnej identity 
(napr. kostol v Giraltovciach, Tročanoch a i.). Z hladiska priestorovej diferenciácie sakrálnych objektov, sme ich najväčšiu koncentráciu identifikovali na východe a severozápade Slovensku, čo korešponduje s ich religióznou štruktúrou. V prípade drobnej sakrálnej architektúry, profánnych, ako aj nehmotných vecí (názvy ulíc, námestí, organizovaných podujatí) sa k náboženskému motívu pridávajú aj motívy historické, sociálne či kultúrne. Práve organizované podujatia založené na cyrilo-metodských tradíciách sa výraznou mierou podielajú nielen na vytváraní genia loci a územnej identity, ale aj na regionálnom rozvoji týchto obcí. Vzhladom na fakt, že vela sakrálnych objektov ( 50 kostolov a kaplniek), ako aj väčšina z profánnych objektov a nehmotných vecí súvisiacich so sv. Cyrilom a Metodom vzniklo až po r. 1989, nedá sa presne určit ich komplexný dopad na krajinu, kedže sa ešte formuje ich vplyv na kvalitatívne vlastnosti krajiny.

\section{REFERENCES}

Antony, Viliam. 2008. Stavebné práce na kostole sv. Cyrila a Metoda. In Bardejovský prameň. 6/34, 5. http://www.ecavbardejov.sk/index.php/co-robime/pramen.

Apsida. 2020. Seniakovce. http://apsida.sk/c/10172/seniakovce.

Bagin, Anton. 1985. Cyrilometodské kostoly a kaplnky na Slovensku. Bratislava.

Bojná. 2019. Cyrilometodské slávnosti. http://www.bojna.sk/cyrilometodske-slavnosti-v-bojnej2019-oznam/mid/214653/.html.

Boltižiar, Martin et al. 2014. Výskum krajiny v príkladových štúdiách. Nitra.

Branč. 2020. O obci - Fotografie - Pamiatky. https://www.branc.sk/pamiatky-foto-kat/mid/50852/. html\#fgallery--2914-3.

Bucher, Slavomír. 2015. Príspevok k poznaniu urbanoným Bratislavy v kontexte ideológie národného socializmu a komunizmu v rokoch 1939 - 1989. In Historický časopis 63/3, 451-481.

ECAV Bardejov. 2020. http://www.ecavbardejov.sk/index.php/o-nas.

Farnost' Velký Krtís. 2020. Filiálka Malý Krtíš. http://velkykrtis.fara.sk/.

Havlíček, Tomáš - Hupková, Martina. 2007. Geografický výzkum religiózní krajiny Česka. In Miscellanea Geographica 13, 161-166.

Havlíček, Tomáš - Hupková, Martina. 2014. Sacred Structures in the Ladscape: The Case of Rural Czechia. In Scottish Geographical Journal 129/2, 100-121.

Heinrichová, Miriam. 2012. Spoločenský prejav a hodnota historickej krajiny. Bratislava.

Heraldický register SR. 2019a. Brodské. http://ives.minv.sk/heraldreg/wp_detail.aspx?ID=833.

Heraldický register SR. 2019b. Nová Bošáca. http://ives.minv.sk/heraldreg/wp_detail.aspx?ID=991.

Hetényi, Martin. 2019. Cyrilo-metodský kult a religiozita na Slovensku v 19. - 21. storočí [The Cyrillo-Methodian Cult and Religiosity in Slovakia from the 19th to the 21st Century]. In Konštantínove listy [Constantine's Letters] 12/1, 141-158.

Hetényi, Martin - Ivanič, Peter. 2017. K problematike percepcie cyrilo-metodského kultu v moderných dejinách Slovenska. In Muzeológia a kultúrne dedičstvo 5/2, 77-91.

Horný Hričov. 2020. http://hornyhricov.sk/podakovanie-cyrilometodske-dni-horny-hricov-2019/.

Huba, Mikuláš. Ed. 1988. Historické krajinné štruktúry. Ochranca prírody - odborná príloha spravodaja MV SZOPK. Bratislava.

Ira, Vladimír - Uher, Ana. 2018. Kultúrna krajina ako kultúrny a časovo-priestorový fenomén. In Životné prostredie 52/4, 195-199.

Ivanič, Peter. 2018. Cyrilo-metodská úcta na Slovensku v 19. a 20. stor. In Ivanič, Peter et al. Cyrilometodějská tradice v novodobých československých dějinách. Zlín, 65-81.

Janas, Karol. 2019. Štefan Závodník a pamiatky zasvätené sv. Cyrilovi a Metodovi v okrese Považská Bystrica. In Konštantínove listy 12/2, 107-116. 
Judák, Viliam - Poláčik, Štefan. 2009. Katalóg patrocínií na Slovensku. Bratislava.

Klátik, Miloš (ed.). 2018. Schematizmus evanjelickej cirkvi augsburského vyznania na Slovensku. Liptovský Mikuláš.

Kowalská, Eva. 2013. Tradicija nacionalnych svjatych Kirilla i Mefodija Vozniknovenie $\mathrm{i}$ ispolzovanije v političeskoj propagande slovackogo nacionalizma. In Slavianovedenije, 48/, 68-78.

Krogmann, Alfred et al. 2017. Religiozita a jej reflexia v cestovnom ruchu na Slovensku [Religiosity and its Reflexion in Tourismus in Slovakia]. In Konštantínove listy [Constantine's Letters] 10/2, 178-190.

Lacika, Ján. 2015. Geografický prístup k výskumu kultúrnych pamiatok a historickej kultúrnej krajiny (na príklade Podmalokarpatského regiónu). In Geografický časopis 67/4, 359-378.

Lexikon. 2019. Nitra, milá Nitra 2019. https://www.lexikon.sk/nitra-mila-nitra-2019/.

Matáková, Barbora. 2012. Duchovné hodnoty vidieckej krajiny v Českej republike a na Slovensku. In Životné prostredie 46/4, 193-198.

Novický, Marek. 2010. Chrám svätého Cyrila a Metoda v Podproči. In Slovo 42/7, 2.

Pamiatkový úrad SR. 2019. Register nehnutelných NKP - Kostol sv. Cyrila a Metoda Lehota pod Vtáčnikom. https://www.pamiatky.sk/po/po/Details?id=4872.

Piva, Elisa et al. 2017. Enhancing Brand Image through Events and Cultural Festivals: the Perspective of the Stresa Festival's Visitors. In Almatourism 8/15, 99-116.

Rakovice. 2019. Obec Rakovice. https://www.rakovice.sk/.

Slovakia travel. 2020. Cyrilometodské dni. https://slovakia.travel/cyrilometodske-slavnosti.

Šantrǔčková et al., 2019. Památky a hodnoty v asociativní krajině sv. Prokopa ve středních Čechách. In Životné prostredie 53/1, 51-58.

Šturák, Peter. 2004. Cyrilometodské dedičstvo v gréckokatolíckych farnostiach na Spiši. In Theologos: teologická revue Gréckokatolíckej bohosloveckej fakulty PU v Prešove 5/1, 75-89.

Trakovice. 2020. Obec Trakovice. https://www.trakovice.sk/.

Úrad geodézie, kartografie a katastra. 2020. Štandardizácia geografického názvoslovia. http://www. skgeodesy.sk/sk/ugkk/geodezia-kartografia/standardizacia-geografickeho-nazvoslovia/.

Vinodol. 2020. Obec - Kultúrno-historický potenciál. https://obec-vinodol.sk/ kulturno-historicky-potencial/.

Zákon o ochrane pamiatkového fondu. 2020. Zákon č. 49/2002 Z. z. https://www.epi.sk/zz/2002-49. Žigrai, Florin. 2000. Dimenzie a znaky kultúrnej krajiny. In Životné prostredie 34/5, 229-233.

Žilinská diecéza. 2020. Patróni. https://www.dcza.sk/sk/dokumenty/dieceza/patroni.

SUMMARY: STS. CYRIL AND METHODIUS AND THEIR REFLECTION IN THE LANDSCAPE OF SLOVAKIA. Both tangible and intangible manifestations of the CyrilloMethodian tradition impact on the formation and transformation of the cultural landscape of Slovakia. Reflection of Sts. Cyril and Methodius in the landscape of Slovakia is processed from the perspective of its temporal, spatial as well as socio-cultural dimension. Out of the tangible elements of the cultural landscape, in terms of both number and impact on the landscape, larger sacral objects (churches and chapels) have a significant share. We have identified 106 objects named after Sts. Cyril and Methodius in 96 municipalities, with up to $73 \%$ of sacral objects occurring in rural areas. It is in the countryside that they play an important landscaping role (e.g. the church in Selce, Lehota pod Vtáčnikom and others). By combining the advantageous location of the object (e.g. top location, outstanding location within the village, etc.) and architectural value, the object becomes a dominant feature of the religious landscape. It participates in the creation of its genius loci as well as its territorial identity (e.g. the church in Giraltovce, Tročany, etc.). The largest concentration of sacral 
objects was identified in the east and north-west of Slovakia, which corresponds to their religious structure. In the case of small sacral architecture, profane and intangible things (street names, squares, organized events), historical, social or cultural motive are added to the religious motive. Just organized events based on Cyrillo-Methodian traditions make a significant contribution not only to the creation of the genius loci and territorial identity, but also to the regional development of these municipalities (e.g. events in Terchová, Nitra, Bardejov, Bojná). More than half of sacral and profane objects, as well as intangible objects, were created after 1989 through the process of modern sacralisation. Due to the fact that their impact on the qualitative characteristics of the landscape is still forming, it is not possible to determine their complex impact on the landscape at the present time.

RNDr. Magdaléna Nemčíková, PhD.

Constantine the Philosopher University in Nitra

Faculty of Natural Sciences

Department of Geography and Regional Development

Trieda A. Hlinku 194974 Nitra

Slovakia

mnemcikova@ukf.sk

Doc. RNDr. Alfred Krogmann, PhD.

Constantine the Philosopher University in Nitra

Faculty of Natural Sciences

Department of Geography and Regional Development

Trieda A. Hlinku 194974 Nitra

Slovakia

akrogmann@ukf.sk

RNDr. Daša Oremusová, PhD.

Constantine the Philosopher University in Nitra

Faculty of Natural Sciences

Department of Geography and Regional Development

Trieda A. Hlinku 194974 Nitra

Slovakia

doremusova@ukf.sk

Doc. Vitor Ambrosio, PhD.

ESHTE (Escola Superior de Hotelaria e Turismo do Estoril)

Estoril Higher Institute for Tourism and Hotel Studies

Av. Condes de Barcelona Estoril, 2765-470

Portugal

vitor.ambrosio@eshte.pt 
Magdaléna Nemčíková - Alfred Krogmann - Daša Oremusová - Vitor Ambrosio - Franciszek Mróz

Dr. Franciszek Mróz, PhD.

Pedagogical University of Cracow

Institute of Geography

Department of Tourism and Regional Research

ul. Podchorążych 2 30-084 Kraków

Poland

fmroz@wp.pl 


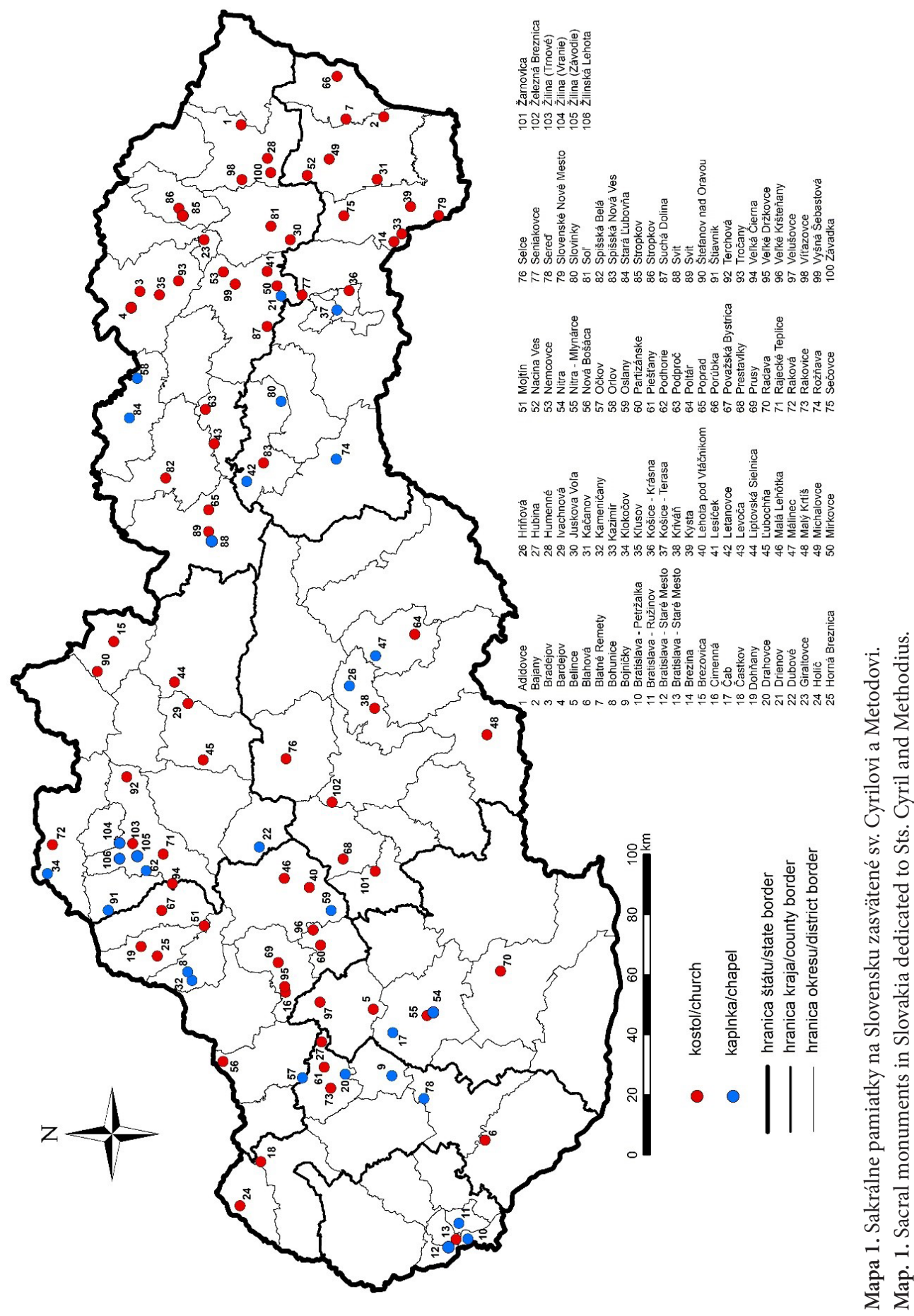




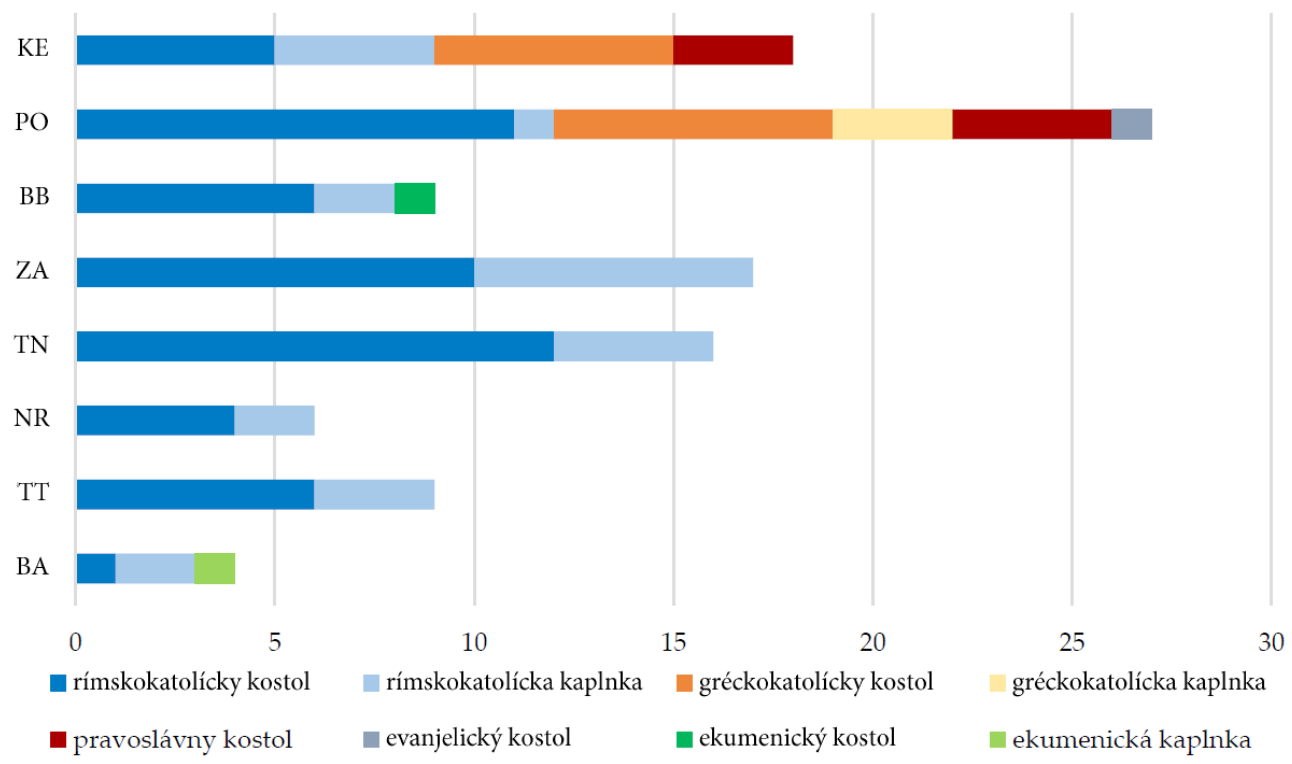

Graf 1. Početnost’ sakrálnych objektov zasvätených sv. Cyrilovi a Metodovi podla krajov, cirkvi a typu objektu. Graph 1. Number of sacred objects dedicated to Sts. Cyril and Methodius by regions, churches and type of objects.

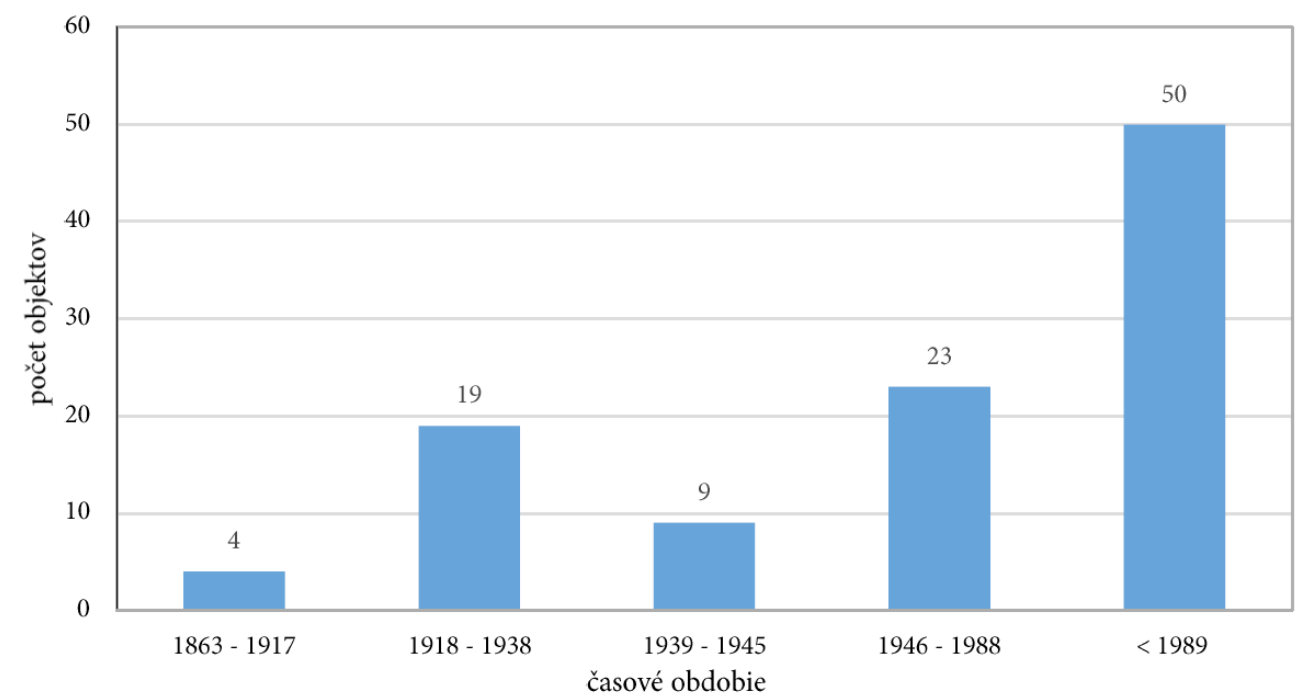

Graf 2. Vývoj počtu sakrálnych objektov zasvätených sv. Cyrilovi a Metodovi podla jednotlivých období. Graph 2. Chronological development of the formation of sacral objects dedicated to Sts. Cyril and Methodius. 